\title{
THE CHALLENGE OF ESTIMATING THE AGE OF SUBTERRANEAN LINEAGES: EXAMPLES FROM BRAZIL
}

\section{IZZIV OCENJEVANJA STAROSTI PODZEMELJSKIH ŽIVALSKIH LINIJ: PRIMERI IZ BRAZILIJE}

\author{
Eleonora TRAJANO ${ }^{1}$
}

\begin{abstract}
UDC 551.44:597(81)

$591.542(81)$

Eleonora Trajano: The challenge of estimating the age of subterranean lineages: examples from Brazil

The applicability and effectiveness of different kinds of evidence used to estimate the age of lineages - morphological, molecular, phylogenetic, biogeographical, geological - are discussed. Examples from the Brazilian subterranean fauna are presented, using mainly fishes, one of the best studied groups, as a model. Only three taxa including troglobites are object of molecular studies, all in progress. Therefore, molecular clocks cannot be applied yet, and indirect evidence is used. Few phylogenies are available, e.g. for the catfish families Heptapteridae and Trichomycteridae. Theoretically, basal troglobitic clades are older than apical ones, but the possible existence of extinct epigean taxa belonging to such clades hampers the comparison. As well, the limitations of the use degrees of troglomorphism to estimate phylogenetic ages are analyzed with focus on the complexity of the mechanisms underlying morphological differentiation. Paleoclimatic reconstructions based on dating of speleothems from caves in northeastern and southeastern Brazil are available, but limited up to the last 200,000 years, thus useful for relatively recent lineages. Topographic isolation, probable for some fish groups from Central Brazil, is also within the time range of $10^{5}$ years. Older dated events (in the order of $10^{6}$ years or more) that may represent vicariant events affecting aquatic lineages with subterranean derivatives are related to the establishment of the modern South American main river basins. In view of the paucity of data useful for estimating the age of Brazilian troglobitic lineages, combined evidence, including morphology, systematics and biogeography, seems to be the best approach at the moment.
\end{abstract}

Key words: evolution of troglobites, degree of troglomorphism, Brazil, subterranean fishes, differentiation rates.
Izvleček

UDK 551.44:597(81)

$591.542(81)$

Eleonora Trajano: Izziv ocenjevanja starosti podzemeljskih živalskih linij: primeri iz Brazilije

$\mathrm{V}$ prispevku je opisana uporabnost in učinkovitost različnih pristopov za ocenjevanje starosti živalskih linij s pomočjo morfologije, molekularne filogenije, biogeografije in geologije. Predstavljeni so primeri podzemeljske favne iz Brazilije, predvsem rib kot najbolj raziskane skupine. Molekularno-biološke raziskave, ki vključujejo tudi troglobionte, opravljamo na zgolj treh taksonih. Molekularne ure zaenkrat še ne moreme uporabiti, vendar zgolj posredne dokaze. Na voljo imamo le nekaj filogenetskih podatkov, npr. za morske zmaje iz družin Heptapteridae in Trichomycteridae. Teoretično so bazalni troglobitski kladi starejši od apikalnih, čeprav verjeten obstoj, sicer izumrlega epigejičnega taksona, ki pripada takim kladom, ovira primerjavo. Omejitve uporabe troglomorfizma za ocenjevanje filogenetske starosti smo analizirali s poudarkom na kompleksnosti mehanizmov, ki so osnova morfološkemu razločevanju. Razpoložljiva paleoklimatska rekonstrukcija, ki temelji na datiranju kapnikov iz jam severovzhodne in jugovzhodne Brazilije, je omejena na zadnjih 200.000 let in je kot taka uporabna le za relativno recentne linije. Topografska izolacija, ki verjetno velja za nekaj skupin rib iz osrednje Brazilije, spada v časovno obdobje $10^{5}$ let. Starejši datirani dogodki (obdobje $10^{6}$ let ali več), ki naj bi predstavljali vikariantske dogodke in ki so pomembni za vodne linije podzemeljskih sorodnikov, so povezane $\mathrm{z}$ razvojem današnjih glavnih južnoameriških porečij. Trenutno je, zaradi maloštevilnih podatkov, najboljša metoda za ocenjevanje starosti brazilskih troglobitskih linij kombinacija pristopov, ki vključujejo morfologijo, sistematiko in biogeografijo.

Ključne besede: evolucija troglobiontov, speleobiologija, stopnja troglomorfizma, Brazilija, podzemeljske ribe, razločevalno razmerje.

\footnotetext{
${ }^{1}$ Departamento de Zoologia, Instituto de Biociências da Universidade de São Paulo, São Paulo, BRASIL; e-mail: etrajano@usp.br Received/Prejeto: 06.12.2006
} 


\section{INTRODUCTION}

The problem of estimating ages for subterranean or any other lineages starts with the very definition of age, whether the time since the isolation from the immediate sister-group (age of the cladogenetic event) or the beginning of differentiation, either the genetic or the morphological one (see Boutin \& Coineau, 2000, for a discussion about the concept of phylogenetic ages). Different kinds of evidence have been used to establish ages of lineages, but their applicability depends on the aspect of age considered. Molecular studies may provide ages of genetic differentiation, independently of morphological change. Dating of potential geological isolation events, such as periods of climatic stress and large scale geological changes, may be used to infer the time in isolation. Inferences about relative times of isolation or differentiation also come out from comparative morphological studies within a phylogenetic and biogeographic framework. Ideally, all evidence should be combined to produce coherent hypotheses about the evolution of subterranean lineages in the temporal scale.

In Brazil, robust molecular studies encompassing exclusively subterranean (troglobitic) taxa started very recently and focus on a few fish groups with very specialized troglomorphic derivatives. Basically three groups are under study with focus on populations or species: the phreatobitic characiform Stygicthys typhlops, from a karst area in eastern Brazil (studied by F. P. L. Marques \& C. R. Moreira); the Amazonian catfish genus Phreatobius, with phreatobic species collected in wells situated in alluvial plains (studied by J. Muriel Cunha); and the heptapterid subterranean catfish from Chapada Diamantina, northeastern Brazil, belonging to the genus Rhamdiopsis (F.A.Bockmann, pers. comm.), previously cited as a "new genus" (studied by R. Borowsky \& M. E. Bichuette). Few phylogenetic studies with biogeographic analyses of larger groups including Brazilian troglobites are available.

Studies aiming to establish the ages of paleoclimatic fluctuations based on speleothem dating are also recent in Brazil, but are progressing quickly. Important climatic changes have been recorded in different karst areas, from the presently semiarid northeast to wet areas in the subtropical southeast. However, these studies are restricted to the late Quaternary, imposing limits to its application to the problem of establishing ages for subterranean lineages because many of these lineages probably have a more ancient origin. Older geological events, such as the Miocene - Plio-Pleistocene important changes that produced the modern Amazon River system, are useful to estimate the age of some Brazilian lineages.

Classically, the degree of troglomorphism, basically the reduction of eyes and pigmentation, has been used as a measure of the phylogenetic age for troglobitic animals (Poulson, 1963; Wilkens, 1973, 1982; Langecker, 2000). In spite of the many restrictions to its generalized application (see below), the degree of morphological specialization may, in certain cases, provide relative ages of isolation in the subterranean environment, being a supplement to molecular and geological evidence.

In the phylogenetic context, a lineage is a branch which departs from one node to another (hypothetical "ancestor"), from a node to a terminal, or an "ancestral" branch plus all the derived terminals, including extinct taxa (which remain unnoticed unless a fossil is known). The present discussion deals lineages including terminals. It must be noted that the ever present possibility of extinction of epigean terminals in a lineage leading to a troglobitic taxon is a source of bias that may produce overestimations of its time of isolation in the subterranean environment.

Among Brazilian subterranean taxa, fishes are by far the best studied group with focus on the currently discussed aspects. Thus, I took basically examples from these animals. For the sake of simplicity, I use herein the term "subterranean" as synonym of "troglobitic" (exclusively subterranean) species, to the exclusion of the equally subterranean, although not exclusively, troglophilic and trogloxenic populations.

\section{DEGREE OF TROGLOMORPHISM AND PHYLOGENETIC AGE:}

The use of the degree of troglomorphism to infer relative phylogenetic ages is based on the assumption that the rates of morphological differentiation are fairly constant among subterranean taxa, at least those regarding eyes and pigmentation, which tend to be lost along the isolation in subterranean habitats. To accept this notion, it is necessary to assume that the mechanisms of reduction are the same for each of these characters and that their reduction progress in parallel. However, there is strong evidence in contrary.

The occurrence of different mosaics of character states in closely related taxa suggests different mecha- 
nisms acting at different rates in each population. An illustrative example is provided by the armored catfishes, Ancistrus cryptophthalmus, from Central Brazil: in the large population found in Angélica Cave, pigmentation is more reduced but eyes are less reduced than in the much smaller population from Passa Três Caves (Reis et al., 2006). A study based on geometric morphometrics showed that the four known populations also differ in general body shape, with a mosaic in the deformation axes, indicating divergence probably due (at least partially) to topographic isolation (Reis et al., op. cit.). Other mosaics are also observed among related heptapterids - among the Rhamdiini, Pimelodella kronei presents eyes more reduced than Rhamdia enfurnada, the opposite being observed for melanic pigmentation.

Such mosaics may encompass a larger number of characters, including behavioral and physiological ones. This is the case with the troglobitic amblyopsids, traditionally ranked in order of increasing degree of reduction of eyes and pigmentation as: Typhlichthys subterraneus < Amblyopsis spelaea $<$ A. rosae (Poulson, 1963). Nevertheless, $A$. spelaea presents more specialized life history traits and feeding behavior, while $A$. rosae is more derived as regards to agonistic behavior and metabolic rates (both subject to reduction); the otherwise less derived Typhlichthys subterraneus is intermediate in relation to agonistic behavior and metabolic rates (Poulson, 1963; Bechler, 1983). Distinct selective pressures are likely to explain such mosaics. For this reason, attempts to rank species like these according to their degree of "adaptation" or specialization to the cave life are unconvincing.

In fact, the reduction of melanic pigmentation in subterranean fishes results from different, independent mechanisms, which may superpose. Morphological mechanisms affect the size and number of melanocytes, whereas physiological ones affect the ability to synthesize melanin. Apparently, this ability may be lost due to different mutations affecting at least distinct two steps in the synthesis of eumelanin, one upstream and the other downstream the synthesis of DOPA: the first corresponds to completely depigmented fish which respond to the administration of L-DOPA by synthesizing melanin, referred as DOPA $(+)$ by Trajano \& Pinna (1996) and tyrosinase-positive by Jeffery (2006); the second correspond to depigmented fish which to not respond to L-DOPA (DOPA(-) albinos; Trajano \& Pinna, op. cit.). Among Brazilian completely depigmented subterranean fishes, Stygichthys typhlops, the new Rhamdiopsis from Chapada Diamantina and the armored catfish, Ancistrus formoso are DOPA(+), the heptapterid "Taunayia" sp. (actually a Rhamdiopsis - F.A. Bockmann, pers. comm.) is DOPA(-) (M.A. Visconti and V. Felice, pers. comm.), and one third of the population of the trichomycterid
Trichomycterus itacarambiensis is DOPA(-), whereas the remaining two thirds have functional melanophores reduced in density.

The morphological mechanism is based on an additive polygenic system (Wilkens, 1988), resulting in a continuous variation in the first evolutionary steps and progressing towards complete depigmentation throughout the population at slower rates than that caused by the loss of the ability to synthesize melanin, which is based on monogenic systems (Wilkens, 1988). For instance, it has been demonstrated that albinism in different populations of Mexican Astyanax is caused by independent mutations in the same gene, Oca2 (Protas et al., 2005). Therefore, very pale but still pigmented fish species, with scattered micromelanophores (such as the Trichomycterus undescribed species respectively from Bodoquena and from Serra do Ramalho karst areas, and the Ituglanis spp. from São Domingos karst areas) may be younger than any of those DOPA(+) "albinos". Thus, the use of troglomorphic pigmentation as a measure of relative age should be restricted to related taxa retaining melanin (i.e., to the exclusion of DOPA albinos), where the degree of paleness is due to mutations in the additive polygenic system underlying the morphological, gradual mechanism.

Regression of eyes is also due to complex genetic systems. In the blind Mexican tetra characins, genus Astyanax, it has been shown that regression is caused by the inactivation of several genes that take part in the developmental control, and that growth factors acting at a lower level of this control appear to be involved in the degeneration of the eyes (Langecker, 2000). Clearly, studies on a much large sample of troglobitic species are needed before any inference about differentiation rates can be made.

Two other factors influence the rates of divergence: population sizes and life cycle strategies. Small populations tend to differentiate faster due to phenomena as genetic drift. Population sizes are highly influenced by ecological factors such as nutrient availability and the extent of habitats suitable for colonization. It is noteworthy that energy is higher in streams (higher carrying capacity), but phreatic habitats occupy larger areas and volumes. Because there is no taxonomic correlation with these factors, related species may differ in population sizes (for instance, populations respectively with 20,000 and 1,000 individuals were estimated for A. cryptophthalmus in Angélica and in Passa Três caves - Trajano, 2001a), thus in divergence rates. As well, nutrient availability may also be "perceived" differently even by taxonomically related species, depending on the efficiency of energy use. Such efficiency may be improved along the adaptation to the subterranean life, allowing for increase in population sizes, then in lowered differentiation rates. 
K-selected life strategies imply lower differentiation rates due to delayed ages for first maturation and low reproductive rates (few individuals reproducing at given times), which work on opposite directions: delayed first maturation implies slow divergence rates (longer reproductive generations), whereas low reproductive rates result in lowered effective populations, which would accelerate divergence rates.
In conclusion, there is a complex balance between different genetic, ecological and biological factors, which may act in different directions to produce the actual divergence rates. Such rates may differ among related taxa, and even among different characters. Therefore, the degree of troglomorphism as a measure of age of subterranean lineages should be used with extreme caution.

\section{GEOLOGICAL, PALEOCLIMATIC AND BIOGEOGRAPHICAL EVIDENCE:}

Dating of paleoclimatic events based on growth phases of speleothems and similar deposits may be applied to subterranean lineages within the framework of the paleoclimatic model (Barr, 1968; Wilkens et al., 2000). However, its cyclical nature imposes serious limitations because, without biological data (molecular, morphological, phylogenetic), it is not possible to establish in which phase the isolation first took place. As a matter of fact, isolation with differentiation may occur along several subsequent unfavorable phases intercalated with coalition phases, thus what really counts to produce genetic and/or morphological divergence is the sum of isolation periods (Trajano, 1995), and not simply the time since the first isolation event.

For instance, in northeastern Brazil there were nine dry phases (no speleothem growth) in the last 210,000 years, intercalated with short wet phases lasting from several hundreds to a few thousand years each. Overall, these periods of speleothem growth occupied only $8 \%$ of the studied period, i.e., around 20,000 years in contrast with 190,000 years with dry conditions, like the one prevalent nowadays in the region (Wang et al., 2004). Hence, at least in the late Pleistocene, there was a much extended period of isolation for the hypogean fauna in northeastern Brazil - for lineages already established in subterranean habitats, from 190,000 to 210,000 years, depending on the occurrence or not of introgression with epigean relatives during the wet periods. As a matter of fact, several of the most highly specialized Brazilian troglobites have been found in this region (e.g., Rhamdiopsis catfishes, Spelaeogammarus amphipods, Pongicarcinia xiphidophorum isopods, Coarazuphium beetles), as well as the only Brazilian troglobitic scorpions, cockroaches and Ctenid spiders.

On the other hand, climatic changes were not as dominant in the subtropical southeast Brazil and dry phases were shorter, at least for the last 116,200 years (Cruz-Jr. et al., 2005). Therefore, total time of isolation in subterranean habitats during the late Pleistocene was shorter in SE than in NE Brazil. Hypothetically, a pop- ulation that became first isolated at a given time in the northeast would be much more differentiated, both genetically and morphologically, than another population first isolated at the same time in the southeast. If one considers "age" as the time of the first isolation, these two lineages have the same age; if "age" is the total time in isolation, then the first one is older. It is clear that, in a cyclical model, the degree of genetic differentiation do not provide a good evidence of age without a precise determination of the duration of each phase.

Geological and geographical events over larger temporal scales may provide more robust evidence. The genus Phreatobius is distributed around the Amazon basin, in tributary basins from both margins of the Amazon River. The first described species, $P$. cisternarum, lives underground in the alluvial fan around the Amazon delta, being collected in shallow hand-dug wells. Much latter, in the 1990's, other species were found deeply buried in submerged litter banks in shallow "igarapés" (small tributaries) along the left margin of the Negro and Amazon rivers. More recently, a second phreatobic species was discovered in wells in the State of Rondônia, Rio Madeira basin, in the right margin of the Amazon drainage (J. Muriel-Cunha \& J. Zuanon, pers. comm..; description in progress by J. Muriel-Cunha \& M. de Pinna). This wide, peripheral distribution of the Phreatobius genus around the Amazon basin may be explained by an origin between the late Miocene and the late Pliocene $(\sim 2.5 \mathrm{Ma})$, when a gigantic lake, or a series of interconnected mega-lakes occasionally united to cover most or all of lowland Amazonia to a shallow depth (Campbell et al., 2006). In fact, Phreatobius catfishes are adapted to shallow, hypoxic conditions, with dark pink to red skin indicating cutaneous breathing; since all known species exhibit this conspicuous trait, this is probably an ancestral condition for the genus. I suggest that the fragmentation of the lacustrine habitat during the late Pliocene, leading to the establishment of the modern Amazon River drainage system, may have been an isolation event for the ancestors of the extant 
species. Nevertheless, an older origin for cannot be ruled out.

On the other hand, P. cisternarum has been found not only north and south of the Amazon River mouth but also in the large Marajó Island in between, with no unequivocal morphological differentiation so far detected between these localities (Muriel-Cunha \& Pinna, 2005). These populations were isolated during the formation of the Amazon delta, 2.5 Ma ago, suggesting a high evolutionary stability, at least at the morphological level, possibly due to the environmental stability of the subterranean habitat.

The disjunct distribution also points to a very ancient origin for the Calabozoidea isopods. So far, this taxon is composed exclusively by three extant phreatobic species, one from the Orinoco basin, in Venezuela (Calabozoa pellucida), e two from Brazil, respectively from the São Francisco (Pongycarcinia xiphidiourus) and the Paraguay (undescribed species) river basins. The only connection between these regions is through the Amazon basin, and I speculate that the ancestors may have dispersed during or prior to the formation of the huge Lago Amazonas. Actually, the São Francisco lineage would be older, at least $5 \mathrm{Ma}$, which is the estimated age of separation of this basin based on studies of the biogeographical patterns in Brazilian freshwater fishes (Hubert \& Renno, 2006). Messana et al., (2002) argue for a close relationship between the Calabozoidea and the Oniscoidea isopods, thus both lineages have the same phylogenetic age, which goes back to the Jurassic-Cretaceous (gondwanic origin - L. A. Souza, pers. comm.). A phylogenetic study, that could add more light to this interesting problem, is waiting for the collection of additional specimens, what is proving to be very difficult in spite of the efforts of biologists and cave divers. Apparently these animals are very rare and/ or live mainly in inaccessible, deep phreatic habitats.

Geomorphological events as alluvial erosion producing waterfalls that split populations (topographical isolation), once dated, also provide data useful to estimate the age of lineages such as the different populations of the armored catfish, A. cryptophthalmus.

\section{PHYLOGENETIC AND MOLECULAR EVIDENCE:}

In order to be minimally reliable and useful, molecular clocks must be based on well corroborated phylogenies with at least one node correlated to geographic or geological isolation events of known age. In cyclical models, such correlation is hampered when cycles are relatively short and repetitive, as is the case with the paleoclimatic fluctuations in the late Pleistocene in Brazil, adding a great deal of uncertainty to the molecular clock. Marine transgressions, which have been used to establish dates for vicariant events in epigean Brazilian taxa such as freshwater fishes, are of no use for subterranean lineages because almost all karst areas in Brazil are above the maximum sea levels. In any case, the conclusion of the molecular studies on Phreatobius spp., S. typhlops and Rhamdiopsis sp. from Chapada Diamantina will certainly open new interesting avenues in this field.

As already mentioned, few phylogenetic studies of groups including Brazilian troglobites are available, most at the genus level and incomplete in terms of taxa encompassed. Among fishes, the heptapterid catfishes were object of a phylogenetic study, but the cave species were not included (Bockmann, 1998). Phylogenetic and molecular studies on heptapterids are in progress, but the position of the Phreatobius genus and of the troglobitic Rhamdiopsis species within this genus are still unclear. Recently analyzed morphological data indicate that, within the genus Rhamdiopsis, "Taunayia" sp. is basal whereas the species from Chapada Diamantina have a more apical posi- tion in the phylogeny (F. A. Bockmann, pers. comm.). These two species independently adapted to the same kind of habitat, the upper phreatic zone connected to the surface through caves (Trajano, 2001b), having developed advanced characters states related to the hypogean life, including miniaturization. "Taunayia" sp., however, is even more specialized, presenting a hypertrophied lateral line system in the head, with behavioral evidence of enhanced mechano-sensory sensitivity. This, associated with its putative basal position in the Rhamdiopsis phylogeny, points to an older age for the lineage to which the troglobitic "Taunyaia" sp. belongs, much anterior to the late Pleistocene.

The phylogeny of the catfish family Trichomycteridae was also studied (Wosiack, 2002), but only one among $10+$ troglobitic species presently known, Trichomycterus itacarambiensis, was included. It is an apical taxa in the phylogeny, indicating a relatively recent origin. A recent derivation of T. itacarambiensis from an epigean ancestor from the Upper São Francisco River basin is consistent with the morphological variation observed in eyes and pigmentation and also with the notion of a quick fixation of genes for albinism, since one third of the population is made of albinos. However, in the absence of a correlation between some node and dated geographic or geological isolation events, it is not possible to estimate an absolute age, even approximate, for this cave lineage. 


\section{COMBINED EVIDENCE:}

For extremes in the inter-taxa variation, the troglomorphism degree may provide good evidence of relative ages. For instance, it is reasonable to suppose that fishes with slightly reduced eyes and pigmentation such as the heptapterids Rhamdiopsis sp. from Cordisburgo (eastern Brazil) and Pimelodella spelaea, from São Domingos (Central Brazil), are younger than the highly troglomorphic Rhamdiopsis sp. from Chapada Diamantina and "Taunaya" sp., from Campo Formoso. The two former species probably have been isolated topographically because they inhabit streams several meters above the base level, and an isolation period in the order of $10^{5}$ years (estimated time for the erosional processes lead to the current landscape - A. Auler, pers. comm..) may be estimated. The two latter species inhabit presently semiarid karst areas in northeastern Brazil subject to extended periods of isolation at least during the last 210,000 years, but they probably became isolated well before. Thus, an estimate in the order of $10^{5}-10^{6}$ years seems reasonable.

A molecular study focusing on the hypervariable Region I of MtDNA did not find any evidence of divergence between the cave populations of Ancistrus cryptophthalmus (Moller \& Parzefall, 2001). However, geometric morphometric analyses showed a clear, statistically significant difference between these populations, but with some superposition with the epigean closest relatives (Reis et al., 2006). Taken together, these data indicate a recent isolation of the cave populations from the epigean ones and also from each other, in the order of $10^{4}$ $-10^{5}$ years.

Preliminary molecular studies on Ituglanis species from São Domingos karst area are consistent with the observed morphological differences (Bichuette et al., 2001) justifying the recognition of four species, each one in a separate microbasin that runs parallel westwards (Bichuette \& Trajano, 2004). These catfishes are sympatric with the morphologically less specialized A. cryp- tophthalmus, P. spelaea and Eigenmannia vicentespelaea (Gymnotiformes), making São Domingos karst area a world hotspot of biodiversity for subterranean fishes. All the Ituglanis catfishes have eyes more reduced and are paler than the other species, presenting scattered melanophores, i.e., they are not DOPA albinos. Three among these Ituglanis species occupy a very specialized habitat, with adaptations to the phreatic environment that include miniaturization. Moreover, I. epikarsticus, and probably also I. bambui and I. ramiroi (Trajano \& Bichuette, unpubl. data), live and disperse through the epikarst, whereas the other species are typical stream-dwellers, like their epigean relatives. In spite of intensive collecting efforts, no epigean Ituglanis catfish was found in São Domingos (the same is true for Pimelodella; Bichuette \& Trajano, 2003). Taken together, these evidences indicate a longer time in isolation for the Ituglanis catfishes. In conclusion, the rich troglobitic ichthyofauna from São Domingos seems to be the result of anachronous isolation events, including both the extinction of epigean relatives due to unknown factors (for Ituglanis and Pimelodella) and topographic isolation (for Ituglanis spp. and also $A$. cryptophthalmus).

Anachronous isolation, possibly in association with different divergence rates, may also explain the disparity in troglomorphic degree observed for the subterranean fauna from the Upper Ribeira Valley karst area, SE Brazil. This fauna includes very specialized species, such as the pseudoscorpion Spelaeobochica muchmorei and the decapod Aegla microphthalma, to moderately troglomorphic species, such as the opilionid Pachylospeleus strinatii, the carabid beetle Schizogenius ocellatus and the catfish Pimelodella kronei. Within the framework of the paleoclimatic model, in view of the short isolation periods (= dry phases) during the late Pleistocene (see above) it is probable that all these species became first isolated in caves before this period.

\section{ACKNOWLEDGEMENTS}

I am grateful to Augusto Auler, Fernando P. L. Marques and Janice Muriel Cunha for the discussion of ideas and criticisms, and to Richard Borowsky for the critical reading and revision of the English style of an early version of the manuscript. Many data were gathered during stud- ies sponsored by the Fundação de Amparo à Pesquisa do Estado de São Paulo - FAPESP (grant n. 03/00794-5, among others). The author studies are also supported by the CNPq (fellowship and grant n. 302174/2004-4). 


\section{REFERENCES:}

Bechler, D. L., 1983: The evolution of agonistic behavior in amblyopsid fishes. Behavioral Ecology and Sociobiology, 12, 35-42, Heidelberg.

Bichuette, M. E., Garz, A. \& D. Möller., 2001: Preiminary study on cave-dwelling catfishes, Ituglanis sp., from Goiás, Brazil, p. 22. In: E. Trajano. \& R. Pinto-daRocha (eds.). XV International Symposium of Biospeleology, Société Internationale de Biospéologie, São Paulo.

Bichuette, M. E. \& E. Trajano., 2003: Epigean and subterranean ichthyofauna from São Domingos karst area, Upper Tocantins river basin, Central Brazil. Journal of Fish Biology, 63, 1100-1121, London.

Bichuette, M. E. \& E. Trajano., 2004: Three new subterranean species of Ituglanis from Central Brazil (Siluriformes: Trichomycteridae). Ichthyological Explorations of Freshwaters, 15, 3, 243-256, München.

Bockmann, F. A., 1998: Análise filogenética da família Heptapteridae (Teleostei, Ostariophysi, Siluriformes) e redefinição de seus gêneros. - PhD Thesis, Universidade de São Paulo, São Paulo, 589 p.

Boutin, C. \& N. Coineau., 2000: Evolutionary rates and phylogenetic age in some stygobiontic species, p. 433-451. In: Wilkens, H., Culver, D.C. \& W.F. Humphreys (eds.). Ecosystems of the World 30. Subterranean Ecosystems (eds.). Elsevier, Amsterdan.

Campbell Jr., K. E., Frailey, C. D. \& L. Romero-Pittman., 2006. The Pan-Amazonian Ucayali Peneplain, late Neogene sedimentation in Amazonia, and the birth of the modern River system. Palaeogeography, $\mathrm{Pa}$ laeoclimatology, Palaeoecology, 239, 166-219, Amsterdan.

Cruz Jr., F. W., Burns, S. J., Karmann, I., Sharp, W. D., Vuille, M., Cardoso, A. O., Ferrari, J. A., Dias, P. L. S. \& O. Viana Jr., 2005: Insolation-friven changes in atmospheric circulation over the past 116,000 years in subtropical Brazil. Nature, 434, 63-66, London.

Hubert, N. \& J.-F. Renno., 2006: Historical biogeography of South American freshwater fishes. Journal of Biogeography, p. 1-23 [www.blackwellpublishing. $\mathrm{com} / \mathrm{jbi}]$

Jeffery, W. R., 2006: Convergence of pigment regression in cave animals: developmental, biochemical, and genetic progress toward understanding evolution of the colorless phenotype., p. 38. In: Moldovan, O. T. (ed.). XVIII ${ }^{\text {th }}$ International Symposium of Biospeleology - 100 years of Biospeleology, Cluj-Napoca, SIBIOS - Société Internationale de Biospéologie.
Langecker, T.G., 2000: The effects of continuous darkness on cave ecology and and cavernicolous evolution, p. 135-157. In: Wilkens, H., Culver, D.C. \& W.F. Humphreys (eds.). Ecosystems of the World 30. Subterranean Ecosystems (Eds.). Elsevier, Amsterdan.

Messana, G., Baratti, M. \& D. Benvenuti., 2002: Pongycarcinia xiphidiourus n. gen. n. sp., a new Brazilian Calabozoidae (Crustacea Isopoda). Tropical Zoology, 15, 243-252, Firenze.

Muriel-Cunha, J. \& M. de Pinna., 2005: New data on cistern catfish, Phreatobius cisternarum, from subterranean waters at the mouth of the Amazon River (Siluriformes, Incertae Sedis). Papéis avulses de Zoologia, 45, 26, 327-339, São Paulo.

Moller, D. \& J. Parzefall., 2001: Single or multiple origin of the subterranean catfish Ancistrus cryptophthalmus. What we can learn from molecular data, p. 38. In: Trajano, E. \& R. Pinto-da-Rocha (eds.). XV International Symposium of Biospeleology, Société Internationale de Biospéologie, São Paulo.

Poulson, T. L., 1963: Cave adaptation in Amblyopsid fishes. American Midland Naturalist, 70, 2, 257-290, Notre Dame.

Protas, M. E., Hersey, C., Kochanek, D., Zhou, Y., Wilkens, H., Jeffery, W. R., Zon, L. I. Borowsky, R. \& C. J. Tabin., 2005: Genetic analysis of cavefish reveals molecular convergence in the evolution of albinism. Nature Genetics, Advance Online Publication, Letters, p. 1-5 [published online 11 December 2005]

Reis, R. E., Trajano, E. \& E. Hingst-Zaher., 2006: Shape variation in surface and cave populations of the armoured catfish Ancistrus (Siluriformes: Loricariidae) from the São Domingos karst area, Upper Tocantins River, Brazil. Journal of Fish Biology, 68, 414-429, London.

Trajano, E., 1995: Evolution of tropical troglobites: Applicability of the model of Quaternary climatic fluctuations. Mémoires de Biospéologie, 22, 203-209, Moulis.

Trajano, E., 2001: Habitat and population data of troglobitic armoured cave catfishes, Ancistrus cryptophthalmus Reis 1987, from Central Brazil (Siluriformes: Loricariidae). Environmental Biology of Fishes, 62, 1-3, 195-200, Dordrecht.

Trajano, E., 2001: Ecology of subterranean fishes: an overview. Environmental Biology of Fishes, 62, 1-3, 133-160, Dordrecht. 
Trajano, E. \& M.C.C. Pinna., 1996: A new cave species of Trichomycterus from eastern Brazil (Siluriformes, Trichomycteridae). Revue française d'Aquariologie, 23, 3-4, 85-90, Nancy.

Wang, X., Auler, A. S., Edwards, R. L., Cheng, H., Cristalli, P. S., Smart, P. L., Richards, D. A. \& C.-C. Shen., 2004: Wet periods in northeastern Brazil over the past $210 \mathrm{kyr}$ linked to distant climate anomalies. Nature, 432, 740-743, London.

Wilkens, H., 1973: Ancienneté phylogénetique et degrees de reduction chez les animaux cavernicoles. Annales de Spéléologie, 28, 2, 327-330, Paris.
Wilkens, H., 1982: Regressive evolution and phylogenetic age: the history of colonization of freshwaters of Yucatan by fish and Crustacea. Texas Memorial $\mathrm{Mu}$ seum Bulletin, 28, 237-243.

Wilkens, H., 1988: Evolution and genetics of epigean and cave Astyanax fasciatus (Characidae, Pisces). Evolutionary Biology, 23, 271-367, New York. 